Check for updates

Cite this: RSC Adv., 2018, 8, 9887

\title{
Enhancement of cellular glucose uptake by reactive species: a promising approach for diabetes therapy
}

\author{
Naresh Kumar, (D) $\dagger^{\star a}$ Priyanka Shaw,$\dagger^{a}$ Jamoliddin Razzokov, ${ }^{a}$ \\ Maksudbek Yusupov, (DD a Pankaj Attri, (D) *a Han Sup Uhm, ${ }^{\text {b }}$ Eun Ha Choi ${ }^{\mathrm{b}}$ \\ and Annemie Bogaerts (D) *a
}

It is generally known that antidiabetic activity is associated with an increased level of glucose uptake in adipocytes and skeletal muscle cells. However, the role of exogenous reactive oxygen and nitrogen species (RONS) in muscle development and more importantly in glucose uptake is largely unknown. We investigate the effect of RONS generated by cold atmospheric plasma (CAP) in glucose uptake. We show that the glucose uptake is significantly enhanced in differentiated L6 skeletal muscle cells after CAP treatment. We also observe a significant increase of the intracellular $\mathrm{Ca}^{++}$and ROS level, without causing toxicity. One of the possible reasons for an elevated level of glucose uptake as well as intracellular ROS and $\mathrm{Ca}^{++}$ions is probably the increased oxidative stress leading to glucose transport.

Received 17th December 2017 Accepted 3rd March 2018

DOI: 10.1039/c7ra13389h

rsc.li/rsc-advances apoptosis of cancer cells. ${ }^{14}$ Recent reports suggest that CAP with lower doses stimulates macrophages to release various cytokine and tumour necrosis factor-alpha, which contribute to the selective killing of a variety of cancer cells. ${ }^{15,16}$ It also promotes stem cell differentiation, ${ }^{17,18}$ enhances cell transfection ${ }^{19}$ and possibly increases wound healing. ${ }^{20}$ Reactive oxygen and nitrogen species (RONS) generated by CAP selectively initiate and amplify ROS signalling to enhance osteoblast proliferation and differentiation. ${ }^{7}$

Recently we investigated that NO species generated by a microwave plasma torch increase myogenesis and significantly elevate the expression of myogenic precursor genes, such as myoD, MHC, and myogenin, which indicates the formation of new muscle tissue. ${ }^{21}$ However, the application of CAP in diabetes mellitus and skeletal muscle cell differentiation investigation are in primarily stage, although it is most likely that CAP might play a role in regulating glucose uptake and myoblast differentiation.

Hence, in order to understand the glucose uptake processes by muscle cells as well as cell differentiation, we apply biocompatible microsecond dielectric barrier discharge ( $\mu$ s-DBD) plasma.

\section{Experimental details}

\subsection{Materials}

Dulbecco's modified eagle medium (DMEM) and fetal bovine serum (FBS) are purchased from Life Technologies. Skeletal muscle L6 cell lines procured from KCLB (Korean Cell Line Bank, South Korea), are used in the experiments. Exogenous $\mathrm{H}_{2} \mathrm{O}_{2}$ and $\mathrm{NO}$ are measured using an Amplex $\mathrm{H}_{2} \mathrm{O}_{2}$ assay kit

(Invitrogen, USA) and a NO detection assay kit (Biovision,

\footnotetext{
${ }^{a}$ Department of Chemistry, University of Antwerp, Universiteitsplein 1, B-2610 Antwerp, Belgium. E-mail: nash.bms@gmail.com; chem.pankaj@gmail.com; annemie.bogaerts@uantwerpen.be; Fax: +32-(0)3-265-23-43; Tel: +32-(0)3-265-23-81 ${ }^{b}$ Plasma Bioscience Research Center/Department of Electrical and Biological Physics, Kwangwoon University, 20 Kwangwon-Ro, Nowon-Gu, Seoul 139-701, Korea

$\dagger$ Equally contributed to this work.
} 
USA), respectively. $\mathrm{H}_{2}$ DCFDA $\left(2^{\prime}, 7^{\prime}\right.$-dichlorodihydrofluorescein diacetate; Invitrogen) is used for the detection of intracellular ROS. $\mathrm{OH}$ and $\mathrm{H}_{2} \mathrm{O}_{2}$ scavengers, i.e., 6-hydroxy-2,5,7,8tetramethylchroman-2-carboxylic acid (trolox), are purchased from Sigma Aldrich. Anti-alpha tubulin antibody, FITC conjugated tubulin and rhodamine-phalloidin, nuclear stain DAPI, are purchased from Abcam USA. A fluorescent probe of glucose, i.e., 2-[N-(7-nitrobenz-2-oxa-1,3-diazol-4-yl) amino]-2deoxy-D-glucose (2NBDG), is used to study the glucose uptake, which is purchased from Invitrogen, USA.

\subsection{Rat skeletal muscle cells (L6) culture}

L6 myoblasts are used to study the cell proliferation and differentiation in a 6-well plate after treatment with the $\mu$ s-DBD. The cells are cultured in DMEM and supplemented with 10\% FBS and $1 \%$ penicillin-streptomycin $(\mathrm{p} / \mathrm{s})$ under standard culture conditions $\left(37{ }^{\circ} \mathrm{C}, 5 \% \mathrm{CO}_{2}\right)$. The cells are seeded onto the 6 -well plate at a density of $5 \times 10^{4}$ cell per $\mathrm{ml}$ and cultured under growth media for $24 \mathrm{~h}$. To induce myotube formation, the media are then replaced with differentiation media (DMEM supplemented with $2 \%$ horse serum and $1 \% \mathrm{p} / \mathrm{s})$. The cells are exposed to $\mu \mathrm{s}-\mathrm{DBD}$ for $30,60,90,120$ and $180 \mathrm{~s}$. Untreated media are included as a 0 min treatment in each experiment. After exposure, on day 2, 4, and 8 the treated L6 cells are used to check the viability through MTT (3-[4,5-dimethylthiazol-2yl]-2,5diphenyltetrazolium bromide) assay. ${ }^{21}$

\subsection{Microsecond dielectric barrier discharge ( $\mu s-\mathrm{DBD})$ plasma device properties and cell treatment}

In this study we use a $\mu$ s-DBD device, previously reported and shown in Fig. 1. ${ }^{12,15}$

It consists of two electrodes, a dielectric layer (silicon dioxide $\left(\mathrm{SiO}_{2}\right)$ ) and hydration prevention layers made of aluminium oxide $\left(\mathrm{Al}_{2} \mathrm{O}_{3}\right)$ and magnesium oxide $(\mathrm{MgO})$. The electrodes have a thickness of $5 \mu \mathrm{m}$ and a width of $200 \mu \mathrm{m}$, and they are separated by a $200 \mu \mathrm{m}$ gap. Diameter of the plasma discharge area is

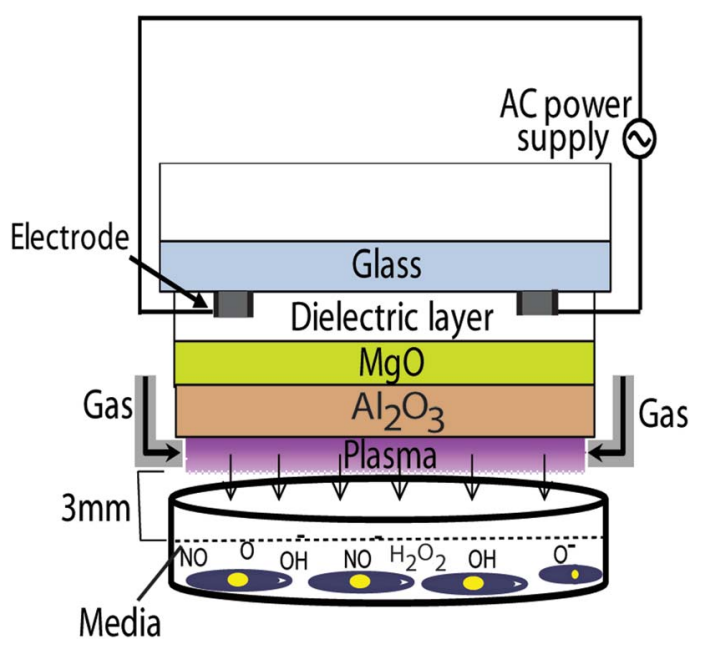

Fig. 1 Schematic diagram of the $\mu$ s-DBD device. Nitrogen is used as a feeding gas with a flow rate of 1 SLM. about $35 \mathrm{~mm}$. To generate plasma, nitrogen gas was injected into the device with a flow rate of 1 standard litre per minute (SLM). A DC-AC inverter system is used for power supply with about $30 \mathrm{~V}$ of primary input voltage. Due to transformer of DC$\mathrm{AC}$ inverter, the frequency of AC power supply is about $30 \mathrm{kHz}$ (see Fig. 1). After confluence of 70\%, the L6 skeletal muscle cells are treated with $\mu \mathrm{s}-\mathrm{DBD}$ plasma for $30,60,90,120$ and $180 \mathrm{~s}$. A constant gap of $3 \mathrm{~mm}$ between the plasma source and the upper surface of the cell culture media is maintained in all experiments. The working temperature of the plasma source is in the range of $20-26{ }^{\circ} \mathrm{C}$. More detailed information about the design and operation of the $\mu$ s-DBD plasma device is given in ref. 15 .

\subsection{Physical and chemical change in the culture media}

After exposure of DMEM in a 6-well plate ( $2 \mathrm{ml}$ per well) to the $\mu \mathrm{s}-\mathrm{DBD}$ plasma, the $\mathrm{pH}$ and temperature of the media are measured using a pH meter (Eutech Instruments, Singapore) and Infrared (IR) camera (Fluke Ti100 Series Thermal Imaging Cameras, UK), respectively. Simultaneously, RONS levels in DMEM media were analyzed after treated with $\mu$ s-DBD plasma for 30, 60, 90, 120 and $180 \mathrm{~s}$. The amounts of $\mathrm{OH}$ and $\mathrm{H}_{2} \mathrm{O}_{2}$ were measured as per previous described methods, ${ }^{\mathbf{1 4}}$ while NO, \& $\mathrm{NO}_{2}{ }^{-}$was measured using the chemical kit.

\subsection{Measurement of protein content}

The total protein content is measured at the designated time points (i.e., on day 2, 4 and 8), after exposing the cells (in media) to the $\mu \mathrm{s}-\mathrm{DBD}$. All of the cell protein extracts from the treated/ untreated cells are lysed in a radioimmunoprecipitation assay (RIPA) buffer (Cell Signaling Technology, USA) and the extracted proteins and protein concentration are measured using the protein assay kit (Biorad, USA).

\subsection{Immunofluorescence staining}

After incubation for 8 days, the treated muscle cells are used to check the cell morphology. The cells on the cover glass are immunofluorescence stained for $\alpha$-tubulin and actin, which are visualized using a fluorescence microscope (TE-2000, Nikon Corp., Tokyo, Japan). The seeded cells are fixed in $4 \%$ of paraformaldehyde in phosphate buffered saline (PBS) and then permeabilized in cytoskeleton buffer $(\mathrm{pH} 6.8,50 \mathrm{mM} \mathrm{NaCl}$, $150 \mathrm{mM}$ sucrose, $3 \mathrm{mM} \mathrm{MgCl}_{2}$, $50 \mathrm{mM}$ Trizma-base, 0.5\% Triton $\mathrm{X}-100)$. After permeabilization, non-specific binding sites are blocked by incubation with 5\% FBS in PBS, and then sequentially incubated with FITC-conjugated $\alpha$-tubulin (1:50). Afterwards, the cell nuclei and actin are stained with DAPI $(1: 5000)$ and rhodamine-phalloidin $(1: 200)$.

\subsection{NBDG glucose uptake}

Glucose uptake studies are carried out by using a fluorescent probe of glucose (2NBDG). ${ }^{22}$ We performed two sets of experiments in a 6-well plate. One set is used for quantification of the 2NBDG uptake. In the other set, the cells on the cover glass are used for qualitative fluorescence imaging. The cells are treated with the $\mu \mathrm{s}-\mathrm{DBD}$ for $90 \mathrm{~s}$ with and without the presence of $100 \mu \mathrm{M}$ 


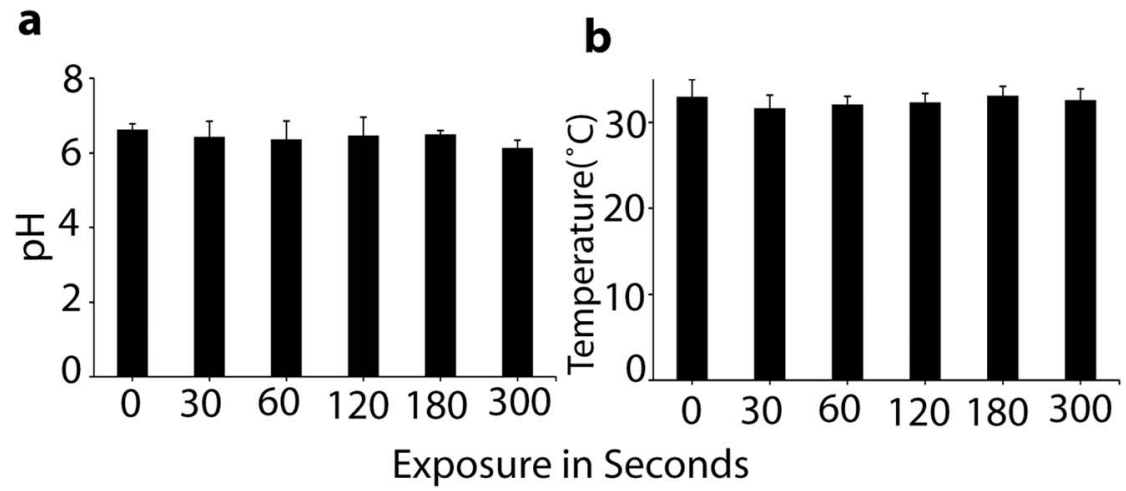

Fig. 2 Measurements of $\mathrm{pH}(\mathrm{a})$ and temperature (b) after plasma treatment of the cell media. All values are expressed as \pm SD in triplicates.

insulin and the glucose uptake is measured on day 2,4 and 8 , using $80 \mu \mathrm{M}$ 2NBDG fluorescent glucose analogue. After $60 \mathrm{~min}$ incubation at $37^{\circ} \mathrm{C}$ with 2NBDG, the cells are washed three times with PBS and then quantified at 485/535 (ex./em.) nm using a microplate reader. The mean fluorescence intensity is calculated between the plasma-treated and control (i.e., untreated) cells. For fluorescence, the image cells are visualized using a fluorescence microscope (TE-2000, Nikon Corp., Tokyo, Japan).

\subsection{Measurement of intracellular calcium levels}

To study the cytoplasmic calcium $\left(\mathrm{Ca}^{++}\right)$level, L6 cells in DMEM are treated with the $\mu \mathrm{s}-\mathrm{DBD}$ for $90 \mathrm{~s}$ with and without the presence of membrane-permeant $\mathrm{Ca}^{++}$chelator 1,2-bis-(2-aminophenoxy)ethane- $N, N, N^{\prime}, N^{\prime}$-tetraacetic acid tetra(acetoxymethyl) ester (BAPTA) on day 2, 4 and 8 in a 6-well plate. The $\mathrm{Ca}^{++}$ concentration in the supernatant material is estimated by the Calcium Detection Kit (abcam, USA). We followed the standard protocol according to the datasheet. For intracellular calcium images, we separately seed the cells on the cover glass in DMEM and treat the cells with the $\mu \mathrm{s}-\mathrm{DBD}$ for $90 \mathrm{~s}$ and $90 \mathrm{~s}+\mathrm{BAPTA} / \mathrm{AM}$. On day 8 of incubation the cells are rinsed with assay buffer (130 mM NaCl, $10 \mathrm{mM}$ glucose, $5 \mathrm{mM} \mathrm{KCl,} 2 \mathrm{mM} \mathrm{CaCl}_{2}, 1.2 \mathrm{mM}$ $\mathrm{MgCl}_{2}$, and $10 \mathrm{mM}$ HEPES, $\mathrm{pH}$ 7.4) and loaded with $5 \mathrm{mM}$ Fura-2 $\mathrm{AM}$ (Invitrogen) for $30 \mathrm{~min}$ at room temperature. The cells are visualized using a fluorescence microscope. ${ }^{23,24}$

\subsection{Quantitative analysis of intracellular ROS content}

To study the total ROS content inside the cells, we use the $\mathrm{H}_{2}$ DCFDA probe. The attached L6 cells in DMEM are treated with the $\mu \mathrm{s}$-DBD for $90 \mathrm{~s}$ and the intracellular ROS content is measured on day 2, 4 and 8 with and without the presence of 1 $\mu \mathrm{M}$ trolox (ROS scavenger), using $10 \mathrm{mM}$ of $\mathrm{H}_{2}$ DCFDA to each sample, and kept at $30{ }^{\circ} \mathrm{C}$ incubation for $1 \mathrm{~h}$. Subsequently, the cells are washed twice with PBS and the intracellular ROS

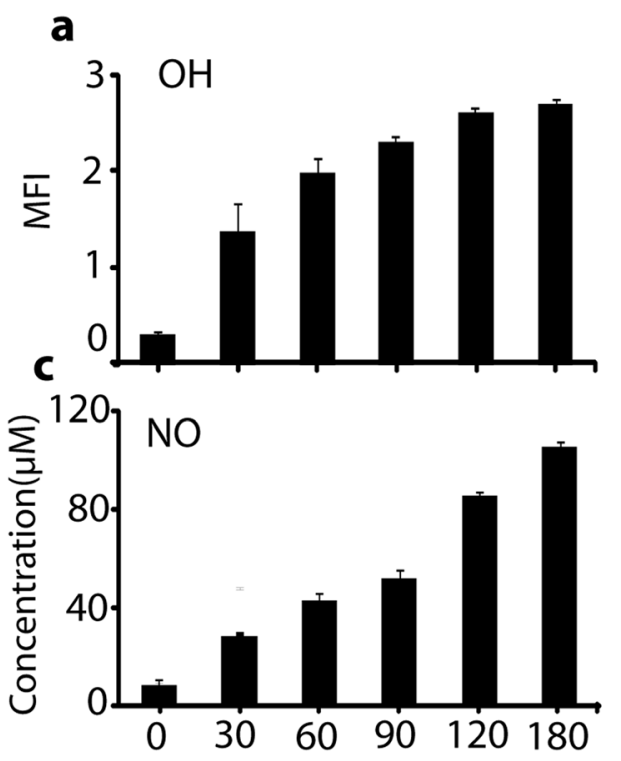

\section{b}

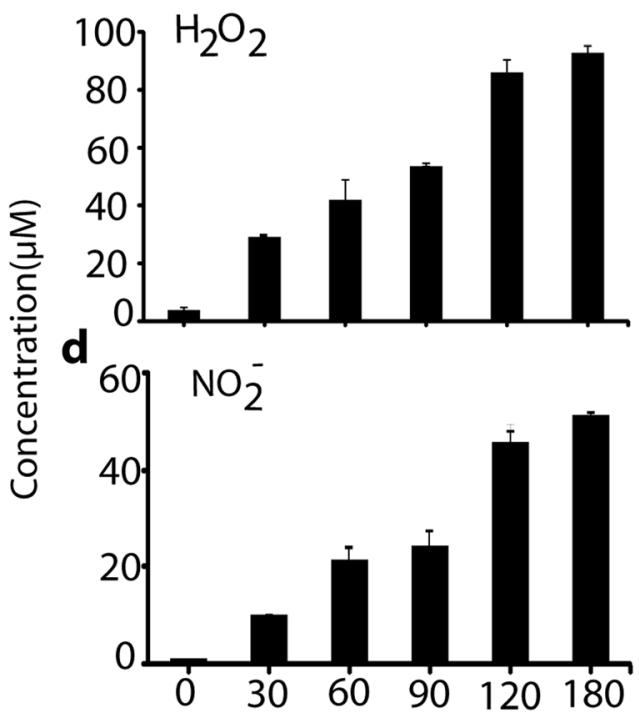

Plasma exposure

Fig. 3 Measurements of the RONS content after plasma treatment of the cell media. Determination of (a) $\mathrm{OH}_{1}$ (b) $\mathrm{H}_{2} \mathrm{O}_{2},(c) \mathrm{NO}$ and (d) $\mathrm{NO}_{2}{ }^{-}$ concentrations in $2 \mathrm{ml}$ media after $\mu \mathrm{s}-\mathrm{DBD}$ plasma exposure at different times. All values are expressed as $\pm \mathrm{SD}$ in triplicates. 


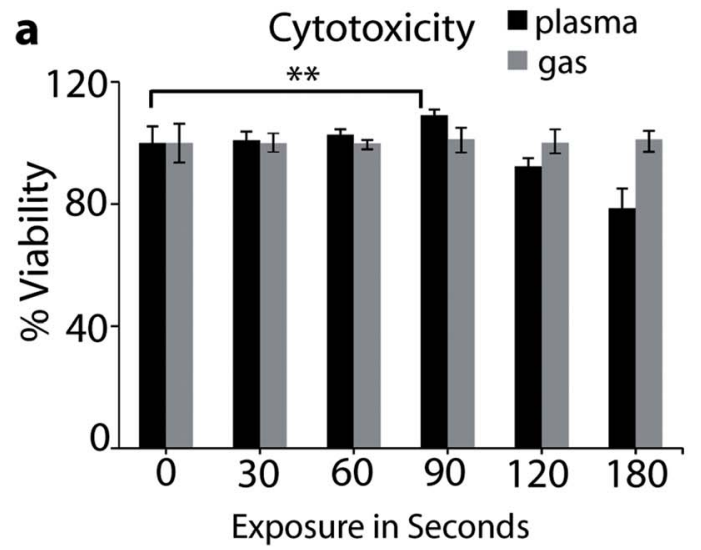

C

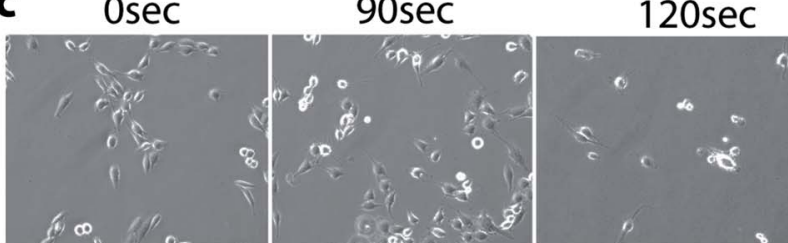

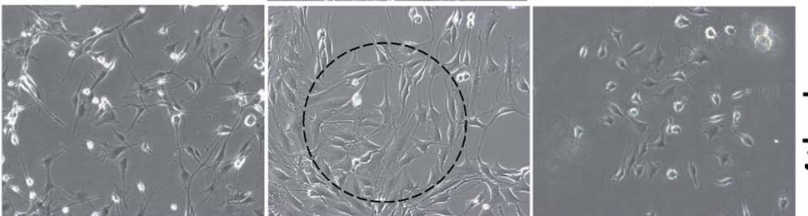
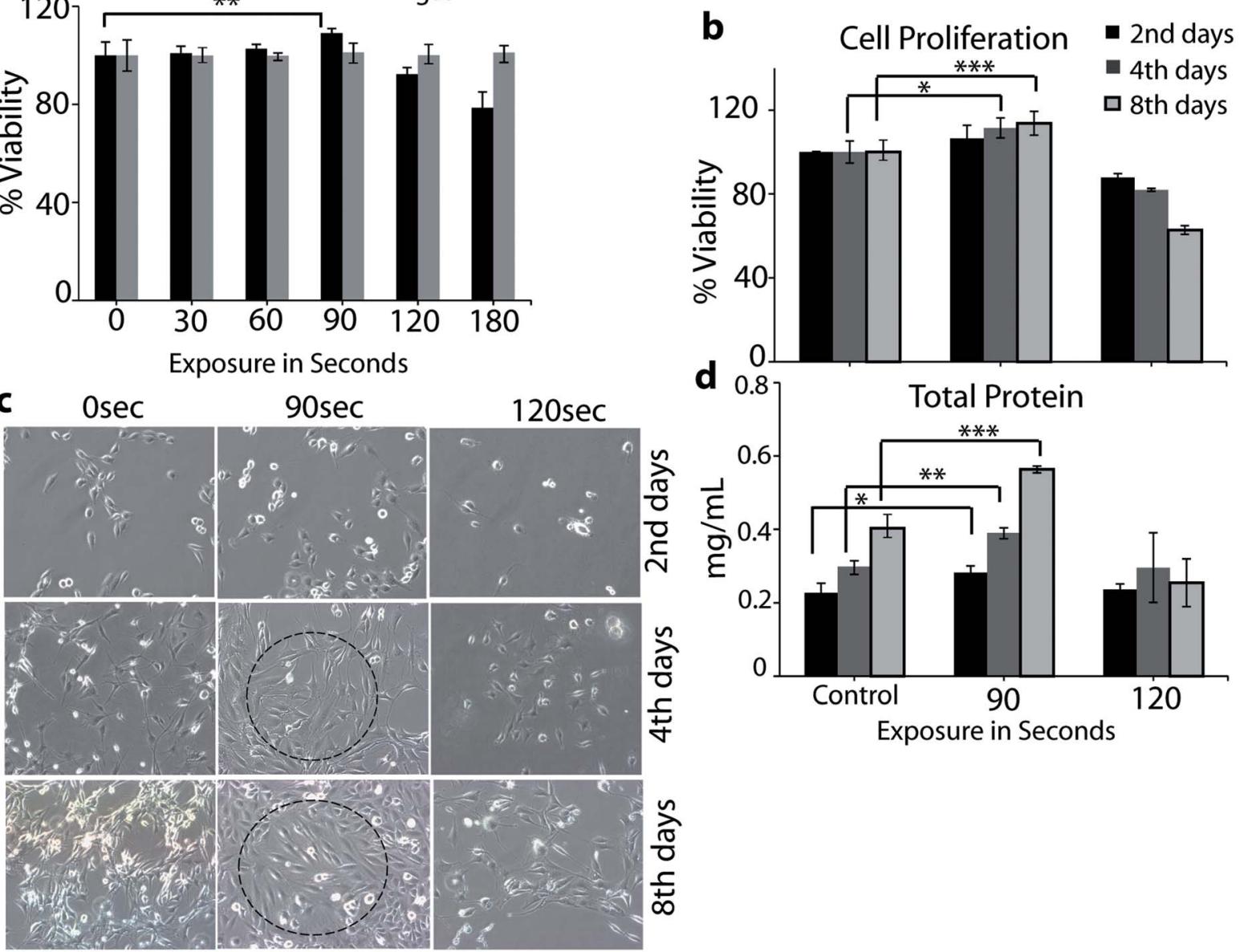

Fig. 4 Analysis of L6 cell cytotoxicity (a), proliferation (b), differentiation (c) and total protein content (d). The cell differentiation analysis was performed using light microscopy, whereas the measurement of the total protein content was carried out on day 2,4 and 8 after exposure to $\mu$ sDBD. Comparison between all groups showed significant differences by one-way ANOVA (* denotes $P<0.05, * *$ denotes $P<0.01$ and $* * *$ denotes $P<0.001$ ).

content is quantified at $495 / 515$ (ex./em.) nm using a microplate reader. The mean fluorescence intensity is calculated between the plasma-treated and control (i.e., untreated) cells.

\subsection{Statistical analysis}

All data values were shown as mean \pm standard deviation (SD). Comparison of all other results was performed by one-way analysis of variance (ANOVA) with Tukey's comparison analysis. The data was considered significantly different when ${ }^{*} p<$ $0.05,{ }^{* *} p<0.01, * * * p<0.001$. Prism (Graphpad Software Inc.) and Excel Software (Microsoft Inc.) was used to compare the groups.

\section{Results}

3.1. Changes in physical and chemical properties of culture media after $\mu s-D B D$ treatment

To determine the changes in the properties of the culture media after exposure to plasma, we applied the $\mu$ s-DBD for 0 ,
30, 60, 120, 180 and 300 s. Fig. 2 shows no significant changes in $\mathrm{pH}$ and temperature.

As is obvious, the temperature of the media was maintained at around $32{ }^{\circ} \mathrm{C}$ during $\mu$ s-DBD exposure, but the $\mathrm{pH}$ of the media slightly decreased after $300 \mathrm{~s}$. These data indicate that up to $180 \mathrm{~s}$, the $\mathrm{pH}$ and temperature have no adverse effect on the cell viability. Further, in order to measure the concentration of extracellular RONS in the media, we applied the same different time points (i.e., 0, 30, 60, 120 and $180 \mathrm{~s}$ ) which were used for the determination of $\mathrm{pH}$ and temperature in the culture media. Fig. 3 shows the concentrations of the RONS in the media treated with plasma up to $180 \mathrm{~s}$.

As is clear, a high amount of $\mathrm{OH}, \mathrm{H}_{2} \mathrm{O}_{2}, \mathrm{NO}$, and $\mathrm{NO}_{2}{ }^{-}$ species inside the solution is observed in comparison to untreated $(0 \mathrm{~s})$ media. Indeed, $180 \mathrm{~s}$ of plasma treatment leads to a production of $\mathrm{H}_{2} \mathrm{O}_{2}$, $\mathrm{NO}$ and $\mathrm{NO}_{2}{ }^{-}$of about 90,100 and 55 $\mu \mathrm{M}$, respectively. However, at a lower plasma dosage (e.g., 60 $\mathrm{s})$, the RONS are generated in moderate quantity, which might influence the cell differentiation as well as the glucose uptake. To examine this, we analysed the plasma effect on the cell 


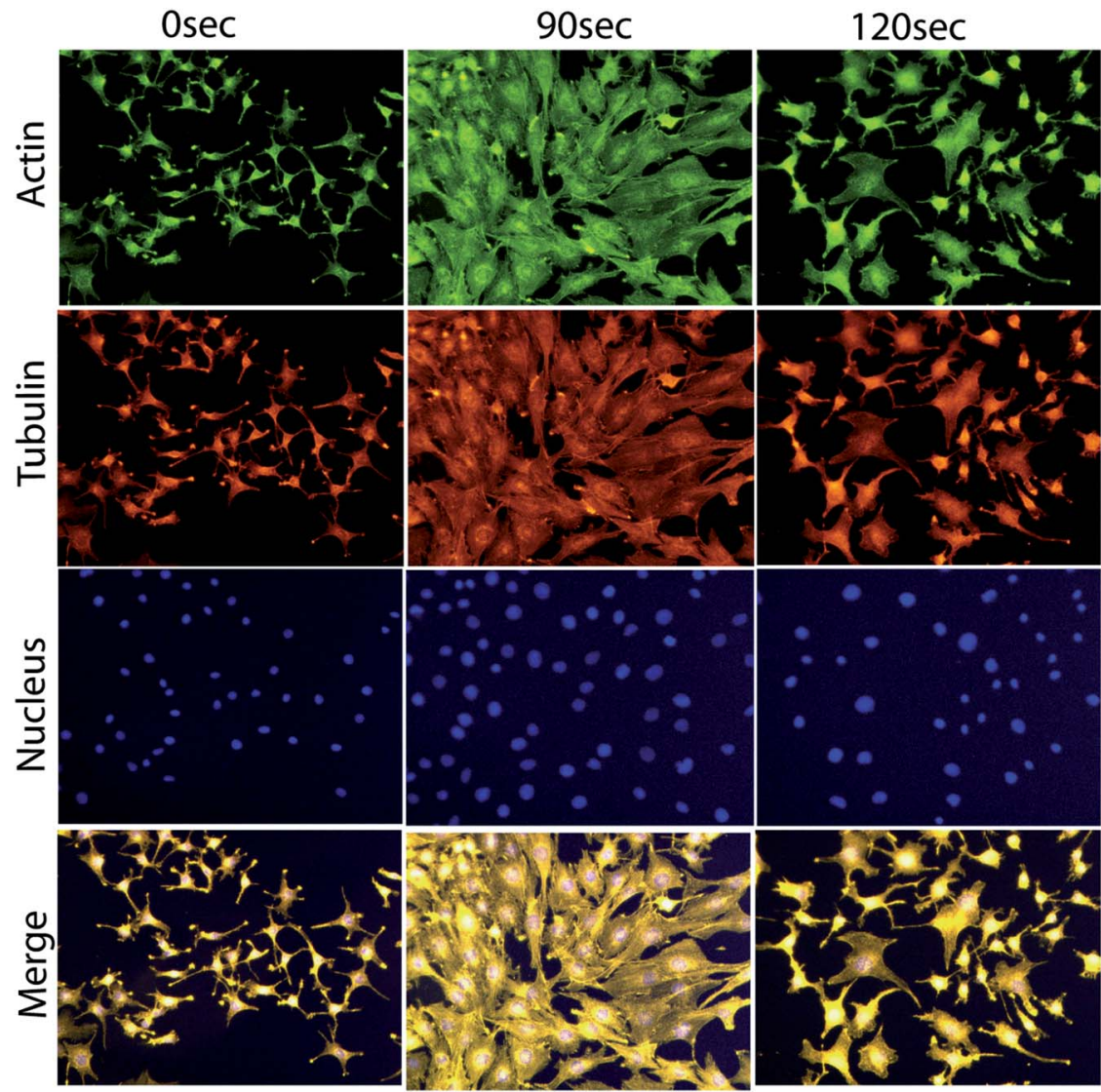

Fig. 5 Cellular differentiation analysis through actin, tubulin and nuclear immunofluorescence images of L6 cells on day 8 after exposure to the $\mu \mathrm{s}-\mathrm{DBD}$

viability, proliferation and toxicity, to determine at which exposure time the plasma triggers the elevation of cell differentiation (see next section).

\section{2. $\mu s$-DBD plasma effects on cell viability and dose optimization}

To find the plasma treatment time and dose at sub-lethal level, the cell viability was studied at different plasma doses. For determination of the cell viability, we performed a MTT assay. The L6 cells showed a significant decrease in viability after treatment with plasma for 120 and $180 \mathrm{~s}$ (i.e., above $90 \mathrm{~s}$ ) during $24 \mathrm{~h}$ of incubation time (see Fig. 4a). However, in the case of only air flow (i.e., no plasma), we did not observe any influence on the cell viability. The MTT assay data showed that the plasma has no inhibitory effect on the growth of the L6 cells up to $90 \mathrm{~s}$. Thus, in the rest of our experiments we used 90 and $120 \mathrm{~s}$ of exposure time to check the cell proliferation. It is clear from Fig. 4b that $90 \mathrm{~s}$ plasma exposure to the L6 cells showed significant proliferation on day 2,4 and 8 , whereas in the case of $120 \mathrm{~s}$, the toxicity of the plasma exposure was noted in the cells (see Fig. 4b). The light microscope images given in Fig. 4c show clear cellular differentiation in the case of $90 \mathrm{~s}$ plasma exposure on day 2, 4 and 8 (see dashed circles).

This indicates that the plasma treatment for $90 \mathrm{~s}$ significantly affects the cellular differentiation on every consecutive day, while plasma exposure for $120 \mathrm{~s}$ represents toxicity (see Fig. 4c). The total protein content of the cells after treatment with the $\mu \mathrm{s}-\mathrm{DBD}$ for $90 \mathrm{~s}$ was greater than that of the untreated cells and the cells treated with $120 \mathrm{~s}$ (see Fig. 4d). Under the exposure of $90 \mathrm{~s}$, confluence of the myoblast cell layers was observed after 2 days of culturing, which continued to increase after 4 and 8 days. Hence, the total protein content indicates that the $90 \mathrm{~s}$ exposure of the cells to the $\mu \mathrm{s}-\mathrm{DBD}$ plasma induces cell proliferation.

\subsection{Influence of the $\mu$ s-DBD plasma on cellular differentiation}

For a more clear observation of the myoblast differentiation after plasma exposure, we performed immunostaining of actin and $\alpha$-tubulin filaments on day 8 of incubation. The average area of the individual myotube was stained with monoclonal antibodies of $\alpha$-tubulin conjugated with fluorescein isothiocyanate (FITC), and the actin filament was stained with rhodamine phalloidin. During the extended cell culture, the L6 myoblast showed a highly organized structure after differentiation into myotubes (Fig. 5), In particular, the majority of the cells cultured on day 8 of incubation showed that the differentiated myotubes were longer and wider in the case of $90 \mathrm{~s}$ compared to those of 0 and $120 \mathrm{~s}$. 


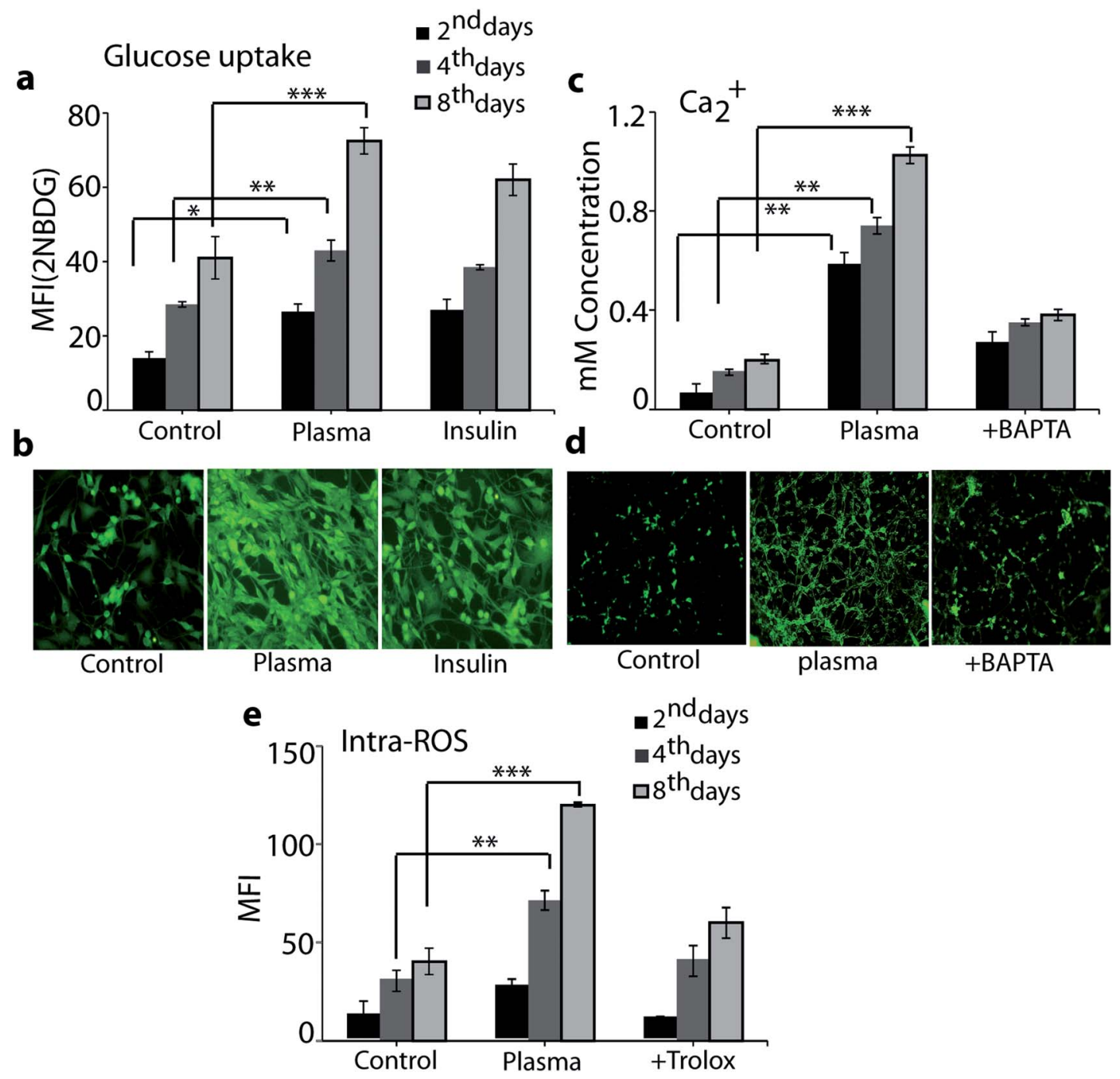

Fig. 6 Glucose uptake (a) and (b), cytosolic $\mathrm{Ca}^{++}$(c) and (d) and intracellular ROS (e) analysis after treatment with the $\mu \mathrm{s}-\mathrm{DBD}$ for $90 \mathrm{~s}$ as well as with insulin (see (a) and (b)), chelator BAPTA (see (c) and (d)) and trolox (see (e)), measured on day 2, 4 and 8 . Fluorescence images of 2NBDG uptake (b) and $\mathrm{Ca}^{++}$(d) were taken on day 8 . Comparison between all groups showed significant differences by one-way ANOVA (* denotes $P<$ 0.05 , * denotes $P<0.01$ and $* * *$ denotes $P<0.001$ )

\subsection{Plasma stimulated glucose uptake, intracellular $\mathrm{Ca}^{++}$ and ROS estimation}

To evaluate the efficacy of plasma in an enhancement of the glucose uptake in differentiated myoblasts, we treated the cells with plasma for $90 \mathrm{~s}$ and analysed the results on day 2, 4 and 8 . Fig. $6 \mathrm{a}$ and $\mathrm{b}$ shows that the plasma treatment resulted in a significant increase in glucose uptake compared to basal levels: the intracellular level of 2NBDG (i.e., fluorescent glucose indicator) increased in differentiated myotube over an incubation time of 2, 4 and 8 days, respectively (see Fig. 6a).

However, $100 \mathrm{nM}$ of the insulin, which is used as a standard drug, also showed enhanced level of glucose uptake in comparison to control (i.e., without plasma exposure), see Fig. $6 \mathrm{a}$ and $\mathrm{b}$. The fluorescent image depicted in Fig. 6b shows that 8 days of incubation has a higher 2NBDG uptake for plasma treatment in comparison to the control and the case of insulin usage. As mentioned in the Introduction, plasma sources (including $\mu \mathrm{s}$-DBD) generate a variety of RONS and these extracellular reactive species are able to penetrate directly or indirectly through the cell membrane, which eventually causes a change in membrane polarity and triggers oxidative stress. ${ }^{25}$ Hence, to observe the influence of plasma on the cell polarity change as well as on the total intracellular ROS level, we analysed the intracellular $\mathrm{Ca}^{++}$and intracellular ROS content on day 2, 4 and 8 in differentiated myotube. Fig. $6 \mathrm{c}$ and d shows the intracellular level of $\mathrm{Ca}^{++}$ions. As is clear, in the plasma treatment case the $\mathrm{Ca}^{++}$level increased in differentiated myotube over an incubation time of 2, 4 and 8 days, compared to the control case. On the other hand, plasma exposure in the presence of $50 \mu \mathrm{M}$ calcium inhibitor BAPTA showed no significant levels of $\mathrm{Ca}^{++}$, which proves that plasma exposure enhances the $\mathrm{Ca}^{++}$levels. The fluorescent image illustrated in Fig. 6d also shows that 8 days of incubation resulted in a higher level of $\mathrm{Ca}^{++}$ fluorescence in the plasma treatment case compared to the 
control and the presence of calcium inhibitor BAPTA. We used the $\mathrm{H}_{2}$ DCFDA diacetate fluorescent probe to detect the total intracellular ROS level. As is clear from Fig. 6e, $90 \mathrm{~s}$ of plasma treatment significantly increased the ROS level in comparison to the control and the presence of $50 \mu \mathrm{M}$ trolox (i.e., ROS scavenger) on day 2, 4 and 8 . These results indicate that the increase of calcium and intracellular ROS level might play a role in stimulation of sugar uptake in the L6 cells as well as in their differentiation.

\section{Discussion}

The main objective of this study was to examine in vitro the plasma effects on glucose uptake through the biocompatible $\mu$ sDBD plasma, aiming at healing diabetic diseases. In addition to the study of glucose uptake, we investigated the differentiation of myoblastic rat L6 skeletal muscle cells. The L6 cell line can reproduce myogenic differentiation in the presence of a growth factor in a culture medium and has been the most widely used model to investigate myogenic differentiation and physical stress stimulated glucose uptake. ${ }^{26,27}$ Initially, we determined the specific $\mu \mathrm{s}-\mathrm{DBD}$ plasma conditions, such as $\mathrm{pH}$, temperature, extracellular RONS content and sub-lethal dose of plasma that is required to maintain the cell viability in response to a certain treatment time of plasma. It was found that $90 \mathrm{~s}$ exposure of $\mu \mathrm{s}-\mathrm{DBD}$ plasma increases the cell proliferation, differentiation as well as total protein content (see Fig. 4). Additionally, the $\mu \mathrm{s}$-DBD treatment also leads to an increase of the intracellular ROS and $\mathrm{Ca}^{++}$content, as shown in Fig. 6 . Previous papers showed that an increase of intracellular ROS content can activate the ion flux through the cell membrane, which influences the intracellular $\mathrm{Ca}^{++}$concentration. ${ }^{28} \mathrm{An}$ increase of $\mathrm{Ca}^{++}$concentration activates the signal transduction pathway that helps to increase the glucose uptake. ${ }^{29,30}$ Furthermore, other research studies also revealed that oxidative stress caused by various factors, such as physical effects, electrical stimulation, etc., help to increase the glucose uptake through an oxidative pathway. ${ }^{4-6,31,32}$ Hence, an increase of the level of intracellular reactive species as well as $\mathrm{Ca}^{++}$ions helps to increase the glucose uptake by skeletal muscle cells. This is in line with our experimental results that an increase of intracellular ROS and $\mathrm{Ca}^{++}$concentration, after plasma treatment, results in an increase of the glucose uptake. Thus, our experimental results might follow the above mentioned mechanism for glucose uptake. Note that there might be other pathways that also help to increase the glucose uptake after plasma treatment. Therefore, further study is required to explain the exact mechanism of glucose uptake induced by plasma treatment.

\section{Conclusion}

Our findings are highly important, since this investigation provides the first evidence of the antidiabetic potential of CAP, as it significantly stimulates glucose uptake and cellular differentiation in L6 skeletal muscle cells. Thus, CAP sources could further be developed for potential usage in antidiabetic therapy. This study is not solely important for diabetes, but might also be essential in cancer treatment, as recent investigations indicate that diabetic patients have $20-25 \%$ more risk of developing cancer compared to individuals without diabetes. ${ }^{33,34}$

\section{Conflicts of interest}

The authors declare no conflict of interest.

\section{Acknowledgements}

We gratefully acknowledge financial support from the Research Foundation - Flanders (FWO), grant numbers $12 \mathrm{~J} 5617 \mathrm{~N}, 1200216 \mathrm{~N}$ and from the European Marie Skłodowska-Curie Individual Fellowship "Anticancer-PAM" within Horizon2020 (grant number 743546). We are also thankful to the Plasma Bioscience Research Center at Kwangwoon University for providing the core facilities for the experimental work as well as financial support by the Leading Foreign Research Institute Recruitment program (Grant \# NRF-2016K1A4A3914113) through the Basic Science Research Program of the National Research Foundation (NRF) of Korea and in part by Kwangwoon University.

\section{References}

1 V. Sarabia, L. Lam, E. Burdett, L. Leiter and A. Klip, J. Clin. Invest., 1992, 90, 1386.

2 P. Galante, E. Maerker, R. Scholz, K. Rett, L. Herberg, L. Mosthaf and H. Häring, Diabetologia, 1994, 37, 3-9.

3 K. G. M. M. Alberti and P. f. Zimmet, Diabetic Med., 1998, 15, 539-553.

4 H.-J. Koh, T. Toyoda, M. M. Didesch, M.-Y. Lee, M. W. Sleeman, R. N. Kulkarni, N. Musi, M. F. Hirshman and L. J. Goodyear, Nat. Commun., 2013, 4, 1871.

5 R. Aslesen, E. M. Engebretsen, J. Franch and J. Jensen, J. Appl. Physiol., 2001, 91, 1237-1244.

6 L. Sylow, T. E. Jensen, M. Kleinert, J. R. Mouatt, S. J. Maarbjerg, J. Jeppesen, C. Prats, T. T. Chiu, S. Boguslavsky and A. Klip, Diabetes, 2013, 62, 1139-1151.

7 I. Han and E. H. Choi, Oncotarget, 2017, 8, 36399.

8 M. Weiss, D. Guembel, N. Gelbrich, L.-O. Brandenburg, R. Mandelkow, U. Zimmermann, P. Ziegler, M. Burchardt and M. B. Stope, In Vivo, 2015, 29, 611-616.

9 M. Weiss, D. Gümbel, E.-M. Hanschmann, R. Mandelkow, N. Gelbrich, U. Zimmermann, R. Walther, A. Ekkernkamp, A. Sckell and A. Kramer, PLoS One, 2015, 10, e0130350.

10 S.-B. Park, B. Kim, H. Bae, H. Lee, S. Lee, E. H. Choi and S. J. Kim, PLoS One, 2015, 10, e0129931.

11 M. Akhlaghi, H. Rajayi, A. S. Mashayekh, M. Khani, Z. M. Hassan and B. Shokri, Biointerphases, 2015, 10, 029510.

12 J. H. Park, N. Kumar, D. H. Park, M. Yusupov, E. C. Neyts, C. C. Verlackt, A. Bogaerts, M. H. Kang, H. S. Uhm and E. H. Choi, Sci. Rep., 2015, 5, 13849. 
13 S. Kubinova, K. Zaviskova, L. Uherkova, V. Zablotskii, O. Churpita, O. Lunov and A. Dejneka, Sci. Rep., 2017, 7, 45183.

14 N. Kumar, J. H. Park, S. N. Jeon, B. S. Park, E. H. Choi and P. Attri, J. Phys. D: Appl. Phys., 2016, 49, 115401.

15 N. K. Kaushik, N. Kaushik, B. Min, K. H. Choi, Y. J. Hong, V. Miller, A. Fridman and E. H. Choi, J. Phys. D: Appl. Phys., 2016, 49, 084001.

16 M. Wang, B. Holmes, X. Cheng, W. Zhu, M. Keidar and L. G. Zhang, PLoS One, 2013, 8, e73741.

17 J.-H. Lee, E.-H. Choi, K.-M. Kim and K.-N. Kim, J. Phys. D: Appl. Phys., 2016, 49, 075402.

18 N. F. Huang, F. Fleissner, J. Sun and J. P. Cooke, Stem Cells Dev., 2010, 19, 1617-1626.

19 M. Leduc, D. Guay, R. Leask and S. Coulombe, New J. Phys., 2009, 11, 115021.

20 S. Fathollah, S. Mirpour, P. Mansouri, A. R. Dehpour, M. Ghoranneviss, N. Rahimi, Z. S. Naraghi, R. Chalangari and K. M. Chalangari, Sci. Rep., 2016, 6, 19144.

21 N. Kumar, P. Shaw, H. S. Uhm, E. H. Choi and P. Attri, Sci. Rep., 2017, 7, 542.

22 N. Kumar, N. K. Kaushik, G. Park, E. H. Choi and H. S. Uhm, Appl. Phys. Lett., 2013, 103, 203701.

23 M. E. Sandström, S. J. Zhang, J. Bruton, J. P. Silva, M. B. Reid, H. Westerblad and A. Katz, J. Physiol., 2006, 575, 251-262.
24 M. J. Kim, H. J. Son, Y. Kim, H.-J. Kweon, B.-C. Suh, V. Lyall and M.-R. Rhyu, PLoS One, 2014, 9, e89062.

25 N. Kumar, P. Attri, D. K. Yadav, J. Choi, E. H. Choi and H. S. Uhm, Sci. Rep., 2014, 4, 7589.

26 Y. Nabeshima, K. Hanaoka, M. Hayasaka, E. Esuml, S. Li, I. Nonaka and Y.-i. Nabeshima, Nature, 1993, 364, 532-535.

27 I. Jun, S. Jeong and H. Shin, Biomaterials, 2009, 30, 20382047.

28 C. L. Ross, M. Siriwardane, G. Almeida-Porada, C. D. Porada, P. Brink, G. J. Christ and B. S. Harrison, Stem Cell Res., 2015, 15, 96-108.

29 A. Fu, C. E. Eberhard and R. A. Screaton, Mol. Cell. Endocrinol., 2013, 366, 127-134.

30 Y. Higaki, T. Mikami, N. Fujii, M. F. Hirshman, K. Koyama, T. Seino, K. Tanaka and L. J. Goodyear, Am. J. Physiol.: Endocrinol. Metab., 2008, 294, E889-E897.

31 E. A. Richter and M. Hargreaves, Physiol. Rev., 2013, 93, 9931017.

32 T. L. Merry and G. K. McConell, IUBMB Life, 2009, 61, 479484.

33 L. Scappaticcio, M. I. Maiorino, G. Bellastella, D. Giugliano and K. Esposito, Endocrine, 2017, 1-9.

34 W.-S. Yang, P.-C. Chen, H.-J. Lin, T.-C. Su, H.-C. Hsu, M.-F. Chen, Y.-T. Lee and K.-L. Chien, Acta Diabetol., 2017, 54, 455-461. 